$\begin{array}{lll}\text { Submitted } & : \mathbf{2 9 . 0 9 . 2 0 2 0} \\ \text { Accepted: } & : \mathbf{0 5 . 1 2 . 2 0 2 0} \\ \text { Year } & : \text { July 2020 Volume: } 1 \quad \text { Issue: } 1 \\ \text { DOI } & : 10.47333 / \text { modernizm.2020164898 }\end{array}$

\title{
THE IDEA OF MODERNISM IN VIRGINA WOOLF'S TO THE LIGHTHOUSE
}

\section{Çağla Kılınç ${ }^{1}$}

\begin{abstract}
Forerunners of literary modernism regarded $19^{\text {th }}$ century literature and realism as inadequate to correspond to the modern crisis of urbanization and industrialization, and shell shock in society. Therefore, they make references to the fragmented, irrational, complex compositions within modernist conscious which is the ultimate consequence of the destruction of civilization, changing world after World War I, and rise of industrialism and capitalism. In this respect, the footprints of the war and its destructive effects are observed in Virginia Woolf's fiction. The goal of this study is to examine Woolf's To the Lighthouse in the light of Modernist theory with reference to "Modern Fiction" and to state that Woolf is a leading modernist figure whose work skillfully contains modernist features, especially stream of consciousness technique and interior monologues to explore the problems of disappointed modern individuals due to great losses and drastic changes in both culture and daily life, to reflect the subjectivity of truth and the impossibility of achieving the objective reality because of each character's different perceptions and to project relativity of time. Woolf's construction of time is independent of the traditional concept of time to provide an effective and non-linear representation of characters' consciousness within conjoined random moments with ups and downs, forward and backward movements, discontinuity and fragmentation. Eventually, the characters of the novel experience devastations of war, and they are mentally affected even though they do not physically engage with it. What war caused correlatively became a crucial determinant in shaping Woolf's literary innovation and To the Lighthouse is the fulfillment of her vision of the modernist novel.
\end{abstract}

Keywords: Modernism, The Great War, Industrialization, Modern Individual, Stream Of Consciousness, Memory, Lighthouse, Marriage.

\section{VIRGINIA WOOLF'UN DENIZZ FENERİ ROMANINDA MODERNIZM FİKRİ}

$\ddot{O} z$

Edebi modernizmin öncüleri, 19. Yüzy1l edebiyatı ve gerçekliğinin, modern kentleşme ve sanayileşme krizine ve toplumdaki savaş sonrası bunalıma karşılık gelmede yetersiz kaldığını düşünüyorlardı. Buna binaen, uygarlığın çöküşü, Birinci Dünya Savaşı'ndan sonra değişen dünyanın, sanayileşme ve kapitalizmin yükselişinin nihai sonucu olan modernist bilinç içindeki parçalanmış, mantıksız, karmaşık kompozisyonlara atıfta bulunurlar. $\mathrm{Bu}$ açıdan, savaşın ayak izleri ve yıkıcı etkileri Virginia Woolf'un yazınında açıkça görülmektedir. Bu çalışmanın amacı, Woolf'un Deniz Feneri romanını modernist kuram 1şında, "Modern Fiction" adlı denemesinden yola çıarak incelemek; Woolf'un başta gelen modernist bir karakter olarak, eserinin hem medeniyetlerinde hem de günlük yaşantılarındaki tesirli değişiklikler ve büyük kayıplar sebebiyle hayal kırıklığına uğramış modern bireylerin sorunlarını, başta bilinç akışı tekniği ve iç monologlar olmak üzere modernist öğeler içerdiğini göstermek; gerçekliğin göreceliğini ve karakterlerin algı farklılıkları sebebiyle nesnel gerçekliğe ulaşmanın olanaksızlığını yansıtmak ve zamanın göreceliğini aksettirmektir. Woolf'un zaman anlayışı, iniş ve çıkışlarla, ileriye ve geriye dönük hareketlerle, süreksizlik ve kırılmalarla birleştirilmiş tesadüfi olaylar içerisinde, karakterlerin bilinçlerinin etkili ve doğrusal olmayan bir temsilini sağlamak amaciyla geleneksel zaman işleyişinden bağımsızdır. Son olarak, roman karakterleri, aktif olarak savaşa katılmasalar da savaşın tüm yıkımını deneyimlerler ve bu durumdan ruhsal olarak etkilenirler. Savaşın sonuçları bağlantılı olarak Woolf'un edebi reformunun şekillenmesinde önemli belirleyici olmuştur ve Deniz Feneri bu modernist roman anlayışının gerçekleşmiş somut halidir.

Anahtar Kelimeler: Modernizm, Birinci Dünya Savaşı, Sanayileşme, Modern Birey, Bilinç Akışı Tekniği, Hatıra, Deniz Feneri, Evlilik.

\footnotetext{
${ }^{1}$ MA in English Language and Literature, Kocaeli University, kilincagla@ gmail.com, https://orcid.org/00000001-5046-3300
} 
In the Modernist Era, filled with negative effects of industrialization and urbanization, rapid social change, and improvements in science, modernist writers felt alienated with Victorian norms, values, optimism, and conventions. In addition, for them, nineteenth-century prose narrative was the promotion of national improvement, industrial enhancement, and artificial publicity of unity and solidarity therefore it was insufficient to stand for the dark side of the human nature and realities of the time. As Mary Ann Gillies and Aurelea Mahood have argued Modern British writers could not disregard the fragmentations in social, political, economic, and daily life so they developed new methods to depict their fragmented feelings and changes in their lives (104). Modernist writers reject the assumptions of 19th century understanding of literature because the Realist movement of that era cannot objectively reflect the concept of reality. Instead, it tries to normalize the traditional and conservative norms and values to make them unquestionable. So, Modernist writers seek new ways to describe the irrational, subjective, meaningless, complex, and unreliable world through fragmented, irrational, complex compositions (Rayment 4). The word modern reflects the contemporary feelings which tell that people live in a new age, deviate from the past, and start to live with a "new conscious", surrounding them, which is modernity (Bradbury 22). It is a new composition that is free of time and space and an experience for the ones who wish to be alienated and isolated. It is the collapse of the traditional structures and styles as the result of the crisis in - culture and society. It may be regarded that modernist writers lived in hard conditions marked with the "historical strain" (26). The Modernist worthies such as Virginia Woolf and James Joyce were quite aware of the crisis and disasters of their own time such as- the destruction of civilization, changing world after World War I, rise of industrialism and capitalism. They eventually provided them with creativity for their writings which were independent of old traditions, carrying a sense of futility, meaninglessness, absurdity, and "aesthetic devotion" (27). So, their works are the products of the destruction of conventional notions and wholeness in society, and the distorted language and transition from the realities to individual subjectivity are the inevitable outcomes. The goal of this study is to examine Woolf's To the Lighthouse in the light of Modernist theory with reference to "Modern Fiction" and to state that Woolf is a leading modernist figure whose work skillfully contains modernist features, especially stream of consciousness technique and interior monologues to explore the problems of disappointed modern individuals due to great losses and drastic changes in both culture and daily life, to reflect the subjectivity of truth and the impossibility of achieving the objective reality because of each character's different perceptions and to project relativity of time.

Woolf was born into an age in which human history had experienced the most rapid and drastic changes in both culture and society. She describes the age in which she was born as" a very communicative, literate, letter writing, visiting, articulate, late nineteenth century world" (DiBattista $\mathrm{x})$. Woolf's parents were Leslie Stephen who was an author, critic, and friend of intellectual and literate people such as, Thomas Hardy and Henry James (Goldman 3). Woolf might be regarded as an advantageous Victorian child because both of her parents were writers and they were acquainted with many Victorian intellectuals, writers, and artists. Sir Leslie's impact on Woolf's intellectual success cannot be denied in that he provided a wide range of libraries to her to support her education. Woolf mentions this opportunity as "allowing a girl of fifteen the free run of a large and quite unexpurgated library" (DiBattista xi). Woolf was a quite lucky Victorian woman because her father was supporting the education of women and recommending Woolf to read biographies, history, poetry, and philosophy books even though she could never receive a formal education apart from some Greek and Latin classes in the Ladies' Department of King's College in London. After her graduation, she made a circle of intellectual friends in Bloomsbury Group which was an elite society composed of young artists and writers (Goldman 8). She could find an opportunity to exchange philosophical and aesthetic ideas on social and political issues and experienced the freedom of expression in the group. She suffered from severe headaches and mental breakdowns throughout her life (DiBattista xiii). Despite all these difficulties, she could improve her career as a novelist, critic, essayist, and reviewer especially with the help of her husband Leonard Woolf who was writing politics and editing periodicals. Even, they established their own publishing house, Hogarth Press, and decided to earn their living through writing (xiv). She published more than five hundred critical essays about social, political, and feminist issues and reviews upon her readings concerning both traditional and contemporary English literature. Her unstable mental state and post-war conditions caused her to 
suicide on 28 March 1941 by drowning herself in the River Ouse with rocks in her pockets (Goldman 24). Leaving behind a lot of significant and revolutionary novels, essays, letters, and reviews, she became an important figure for the feminist movement and modernist writing. When it comes to Woolf's modernist style, it is observed that Woolf uses interior monologues to reflect what her characters feel and think and the stream of consciousness in which characters' thoughts flow in an irregular path as opposed to linear narratives of her contemporary time. On the surface, her works might seem to be composed of random thoughts and arbitrary incidents; however, as Esra Aytaç points out, what Woolf does with this unusual narrative is to show how post-war conditions and drastic changes in social life and culture may affect lives and create problems in individuals and their relations (9). Woolf's concept of reality is completely personal and free from traditional values because she believed it was impossible to acquire an absolute truth out of existing conditions which justifies the reason for this attitude: Modern civilization left modern individuals disappointed; and the advantages of civilization and scientific progress damaged the hopes of a comfortable and peaceful future. Instead, it created a Great War, which had remarkable effects on Modernism and Woolf's literary style. The effects of the destructions of the Great War made Woolf's generation feel mistrust towards civilization and existent truth and values. In this respect, the footprints of the war and its destructive effects are felt in her fiction To The Lighthouse belongs to the period which is called "The explosion of Modernism", so Woolf was aware of the generation she belonged and she knew that she was an innovator for she created new ideas, forms and patterns for Modern Novel (15). Her concept of reality comprises a merged past and the present moment in the individual's mind. Her approach to the modern individual's condition enabled her to deconstruct the whole structure of the novel and to create a technical innovation. As Esra Aytaç points, "Woolf's main concern was the consciousness of her character which keeps flowing like a stream of thoughts" (10). The view of multiple stages of consciousness prepares an understanding of time which flows constantly rather than create a series of separate moments. Therefore, she aims to immerse the reader into the characters' consciousness to tell their story, instead of offering a chronological work with a framework.

"Modern Fiction" is another important work of Woolf in that it reflects Woolf's aesthetic of modernist writing. Woolf explains her vision of the modern novel by defining it against the materialistic fiction of H.G. Wells, Arnold Bennett, and John Galsworthy. In the mentioned essay, she claims Edwardian authors as materialists because they are concerned with the body rather than the spirit. In other words, they deal with nonessential things in their writings such as a detailed description of exterior details, clothes of the characters, or furniture in a room (Woolf 160). As an example, Wells provides a regular and wealthy life for his characters. On the contrary, Woolf wants to see the feelings and thoughts of the characters. She criticizes them for being too dependent on conventions because all these writers are inspired by the same incidents and no one attempts to go beyond their literary limits. So, their works are on the one hand too artificial, popular, and commercial, on the other hand, too political, class-conscious, and didactic. For example, Bennett's construction of a book is so perfect and solid with predictable and plausible plots that critics cannot analyse the work flexibly (Woolf 159). Woolf thinks that spirit? or life, truth or reality are the essentials of a novel; however, writers are obliged to produce a plot including comedy, tragedy, and love interest which makes the work unnecessarily perfect (160). Here, she does not criticize their effort and skill of writing; rather, she criticizes their use of the talent on trivial and unimportant things. According to Woolf, literature mirrors life itself. So, when we look at life itself everything is quite random and there are several possibilities in life. She supports the freedom of writers in writing whatever they prefer to write and following their feelings instead of conventions. According to Woolf, they would be the "slaves" of traditional conventions if they do not follow their interests (160). So, writers should let themselves go within the unpredictability and complexity of life. They should present the ideas explicitly in the first minutes of coming to mind. In other words, the consciousness of the characters and writer should not be limited with rigid arrangements no matter how incoherent it seems. At first, their tendencies might seem different and incomprehensible to their predecessors. However, she reminds her contemporaries that there is no limit, no specific and proper method of fiction (163). Similarly, Woolf wanted to write fiction that captures the "life itself" and unrestrained spirits of her characters, and To the Lighthouse is the fulfilment of her vision of a modern novel. 
The novel carries autobiographical elements and particularly includes Woolf's childhood memories. Her parents, Leslie and Julia Stephen constitute the birth of Mr. and Mrs. Ramsay in To The Lighthouse. The year Woolf was born, the family moved to Talland House in St. Ives, Cornwall, for the summer and spent their time playing in the garden, walking along the coast from where they could observe the Godrevy lighthouse (Aytaç 1). These memories created the basis of the family scenes in the section "The Window" in which Mr. and Mrs. Ramsay and their eight children visit their summer house in the Hebrides, a group of islands in Scotland. Their house stands in front of a lighthouse across the bay. The Ramsay family and their guests are depicted during a day. Then a passage of ten years takes place in the section of "Time Passes" during which Mrs. Ramsay dies and the World War I erupts. In the novel's final section, "The Lighthouse", Lily manages to complete her painting, and Mr. Ramsay and his two children, James and Cam who feel hatred towards their father deep inside of themselves, finally reach the lighthouse. In the first section of the novel, Mrs. Ramsay is the central figure. Even though she is aware of the imperfect nature of existence, her role in life is to bring joy and happiness to people around her and to protect and comfort her children's enhancement of childhood. When looking from outside, she is charming and disseminates harmony and peace. However, there is conflict, fear, and anxiety in her inner world. She sees life as her opponent who is ready to betray her any time: "hostile, terrible, quick to pounce on you if you gave it a chance" (70). Consequently, the dualism between her inner states of fear and threatening reality shapes Mrs. Ramsay's character and contributes to her personality's evolution. When she is alone, she feels relieved because she can leave her surface personality and she can be free from reality and conflict in her private world. On the other hand, the light from the lighthouse reflects her ideal self, her beauty, and her strength (Guth 238). In time, she realizes that the cover of loveliness is not sufficient to veil her hidden grief. In the great dinner event, she sits at the dinner table, feels the defeat deep inside, and asks herself, "What have I done with my life?" (58) She has a sense of nostalgia for everything: "It's all come to an end as if a shade had fallen and she saw things truly" (94). The dinner party, which she presides, reflects her mood; similarly, everyone feels empty, isolated, and separated. Her evolution takes shape in three steps: her initial perception of the lighthouse, her realizing hidden self and readers' realizing her suffering, and finally her "rebirth from pain to serenity" as her deeper self leaves the real world with a mysterious death (Guth 241).

At the same time, the novel presents a non-linear evolution of time from the realm of the imaginary which belongs to Mrs. Ramsay, to the real world which is protected by Mr. Ramsay. In this sense, while there is continuity between the worlds of Mr. and Mrs. Ramsay, their conflict between two different attitudes can never "coexist" (Guth 237). At the beginning of the novel, the reader observes cracks and conflicts in Ramsays' seemingly happy marriage. Both Mrs. and Mr. Ramsay have competing world views; for instance, Mrs. Ramsay regards the waves in the section "The Windows" as "a measured and soothing tattoo to her thoughts", then as "a ghostly roll of drums remorselessly beating the measure of life" (21). Her perception of waves changes from an understanding of a consoling element of nature like a lullaby to the ideas referring to the destruction of the island. They have disconnection in their relationship due to minor issues such as deciding on going to the lighthouse or not. By doing so, Woolf creates an irony in the concept of marriage: while two people try to create unity, they can clash over trivial things. This little disagreement caused Mrs. Ramsay to unwittingly think about the dissatisfaction with her marriage. She starts to question their marriage due to a basic problem even though they seem to complete each other. The idea of being isolated from Mr. Ramsay sounds comfortable to Mrs. Ramsay who constantly soothes her husband (Collins 2). On the other hand, it is understood that Mrs. Ramsay fears being alone which is almost the only motivation for her marriage. What is more, she has doubts about the success of the marriage's ability to provide the needed human intimacy while she tries to impose the benefits of marriage on her daughters, Lily Briscoe and Minta Doyle. Mrs. Ramsay's attitude portrays modern society's approach towards the concept of traditional marriage. The marriage of Mr. and Mrs. Ramsay effects all the characters who wish to have such a serene relationship in their lives. Even though she questions her marriage and cannot experience satisfaction through her marriage, she encourages other young women about getting married. On the other hand, as a young artist, Lily Briscoe questions the sincerity of the marriage institution (1). She chooses between her art and getting married which has social restrictions. She chooses her painting instead of acquiring intimate relations through marriage because this kind of 
intimacy is unable to satisfy her. In a similar attitude with that of Lily, Mr. Ramsay sees his marriage and children as - entanglement in his intellectual progress because being unaware of Mrs. Ramsay's unifying power, Mr. Ramsay regards his family as indigent for his protection (6). The opposite way around, he needs Mrs. Ramsay's comforting presence and he is taking shelter in her emotional conciliation while he regards his wife as too simple-minded to appreciate his philosophy and poetry. As an example, he thinks she does not understand anything while Mrs. Ramsay reads a line from a poem. In a way, Mr. Ramsay cannot feed his creative side along with his marriage. He feels as if he had to choose a side between being a complete philosopher and a family man.

Lily Briscoe stands for the next generation after the Ramsay family and as a painter, she suffers from modern conditions just like other characters in the novel. She breaks the traditional Victorian concept of marriage by refusing to take the side of either being an artist or a married woman. Besides, getting married for the sake of providing intimacy is not suitable for her point of view. On the other hand, she chooses her painting over any kind of intimacy when she needs to choose between her painting and creating intimate relations with other people. In the novel, Lily is not successful in creating any kind of intimacy with people around her. Her struggle is apparent in her relations with Mrs. Ramsay, Charles Tansley, and William Bankes (10). At first, she rejects Mrs. Ramsay's advice about marriage and she does not let Mrs. Ramsay - create an ideal world for her. While creating her abstract painting, Lily starts to understand other characters' state of mind, especially hers, as vanishing the image of the impossibility of creating - intimacy among other characters. In a way, Lily is the representative of a Victorian artist who struggles to find a place in the Victorian understanding of intimacy. Lily isolates herself from - society through her art. Also, she isolates her art from people around her because she worries that they fail to appreciate her art. Lily seeks her independence by creating new forms of art and Mrs. Ramsay regards her attitude as an odd and childish approach. She abstains from any exchange with other characters especially when it is about her painting. She usually prefers to observe - others silently. Despite her abstaining manner, she lets William Bankes - enter her world and exchange some ideas about marriage. Through these scenes, it is understood that Lily's painting and artistic point of view stand for her rebellious ideas against traditional Victorian norms. Even though she admires the bond between Mr. and Mrs. Ramsay, she does not believe in the joy of love and marriage. Her painting echoes the marriage and relations between Mr. and Mrs. Ramsay in that both are in search of hope. What stimulates Lily about choosing between being an artist and a traditional Victorian woman is Charles Tansley's statement, "Women can't paint, women can't write" (48). At first, she hesitates in her painting as well, as she experiences internal struggles: she fails to become a traditional Victorian woman because she is neither a wife nor a mother. She thinks what if she is not a real artist because she failed to create intimacy as Charles Tansley indicates. If she fails to create intimacy with people, she might fail in her painting, too. Later, as a modern artist, her solution for lack of emotions and intimacy is finishing her painting. One of the reasons why Lily admires Mrs. Ramsay is her ability to create relationships with other characters. Lily questions the nature of human intimacy which she can never achieve and reflects it in her painting. Her inner struggle of deciding whether to be a Victorian woman or an artist creates an artistic talent manifested in her painting (Collins 18). Her art seems confusing to Mr. Bankes and requires an explanation for him. She likens the scene in which Mrs. Ramsay reads a story to James to a purple triangle. For she is incapable of comprehending human intimacy, she reduces the feelings of mother and the bond between a mother and son to the shape of a purple triangle. What is more, her art is not easy to understand because she breaks the traditional ways in her style, just as she rejects the traditional manners in her personal life.

Returning to the construction of modernism, fragmented and incomplete bodies occupy an important place in its form. Matter and form had been changing since World War I that brought the modern crisis of urbanization and industrialization providing free-floating illness, neurasthenia, shell shock. The harsh consequences of war have become an important determinant for shaping Woolf's literary style which is a literary innovation in terms of mirroring the consciousness of her characters. Woolf's stream of consciousness writing is canonized in the characterization of modernist literature as narrated from the characters' mental interiority and discoursing mind rather than plot (Wood 485). The novel draws the characters and the readers to hypnotizing affairs of perception and thought. The real world gives place to a symbolic landscape by creating a novel dealing with outward situations rather than people. The readers follow the inner states and feelings of the characters. Their feelings pass 
through one character to another by creating a unified experience with Mrs. Ramsay's anxieties of the future, Lily Briscoe's search for herself, and Minta's sorrow for the entire world. The novel, which is compensated between the real world and field of meaning, is between the visionary and real and the dream and truth (Guth 233). It has a rhythm within the language and thought which creates a sense of continuity in intermittent patterns and truths. The section of "Time Passes" evokes a consciousness whose narration relies on sensation because what time steals from the house is observed by imagined eyes. "Listening (had there been any one to listen) from the upper rooms of the empty house only gigantic chaos streaked with lightning could have been heard tumbling and tossing, as the winds and waves disported themselves..." (151) This section explains the physical situation of the house, creates a sense of perception as if someone watches the house and hears the voice of waves and rustle of leaves. Whether there is someone who experiences these facts or not, the perspective and sensations still provide observing the consciousness. The novel also portrays the mentality of civilians who do not actively participate in the war. However, they experience the constant threat, caused by the sounds of the war which prevents them to forget. The sounds reach them as follows:

the measured blows of hammers dulled on felt, which, with their repeated shocks still further loosened the shawl and cracked the tea-cups. Now and again some glass tinkled in the cupboard as if a giant voice had shrieked so loud in its agony that tumblers stood inside a cupboard vibrated too. Then again silence fell; and then, night after night, and sometimes in plain midday when the roses were bright and light turned on the wall its shape clearly there seemed to drop into this silence this indifference, this integrity, the thud of something falling. [A shell exploded. Twenty or thirty young men were blown up in France, among them Andrew Ramsay, whose death, mercifully, was instantaneous]. (149)

Here, the death of Andrew Ramsey is reported to the reader in addition to never-ending and ongoing death and destruction. There is suffering from a sense of loss, fear, helplessness and, alienation. War caused great changes in individuals and every sphere of life. The change might be caught from the following lines: "But dear, many things had changed since then; many families had lost their dearest. So, she was dead; and Mr. Andrew killed; and Miss Prue dead too, they said, with her first baby; but everyone had lost someone these years" (153). As time passes, death dominates the work. This devastated state of mind is reflected through the wrecked situation of Ramsey house which is falling apart step by step depicted as "all damp in here; the plaster was falling. [. . .] gone mouldy too. And rats in all the attics" (154). Life leaves perished characters and this sense of destruction is reflected in the deserted house and the process of the house's decay.

Just as the lighthouse stands in the middle of the sea, it is at the centre of the novel's universe in that its distant light stands between characters and their inner struggles and goals. The lighthouse has different meanings for each character; however, for each character, it is the centre of the existential conflict, correspondence of inner nature, and symbol of resolution. As an example, Mrs. Ramsay is linked to the sea and her life contains all the beauty and mystery of the sea. She constantly expresses herself with the waves which "reach out some infinity, then, gathering themselves in, move back and subside" (234). Thus, the lighthouse finds correspondence in her yearnings as a distant place to which her gaze returns again and again. For her, its light covers the darkness of human suffering. At the same time, the lighthouse contains her secret sorrow which she tries to hide throughout her life. The lighthouse has a different meaning for Mr. Ramsay; it is the image of immutable truth, the strictness of his intellect, and his rigid determination. In this way, the characters' inner and outer worlds and dreams and reality complete each other. While the lighthouse stands for Mrs. Ramsay's obscure inner movements in which different elements of life are compromised, it is the symbol of Mr. Ramsay's battle over life itself. On the surface, the lighthouse has a complementary function in their marriage as Mrs. Ramsay finds peace in the lighthouse from her anxieties about her husband's stability. On the latent level, the lighthouse brings light to the problems in their marriage, especially by showing their different attitudes to life. The essence of the lighthouse symbol lays at the symbol of light itself. The lighthouse appears for the first time in the section "The Window", as a rigid vertical which dominates horizontal planes of land and sea (Stewart 377). It is seen by Mrs. Ramsay as part of "view...that her 
husband loved" (16). So, the light is a positive force and the lighthouse stays in the realm of emotion, intuition, dreams, and unconscious. Next, the lighthouse appears as a distant object and as a source of light in the section "Time Passes". When Mrs. Ramsay sees the light reflected from the lighthouse in James's eyes, she also sees a reflection of her dreams in his eyes. So, Mrs. Ramsay identifies herself with the light. "Often she found herself sitting and looking, sitting and looking with her work in her hands until she became the thing she looked at-that light for example" (72). The lighthouse beam is transformed into a being when Mrs. Ramsay experiences the intensity of life as she puts the spiritual reality of light (Stewart 378). Also, as being a wife, mother, and component figure of their society, Mrs. Ramsay becomes a source of light for others due to her roles. As an example, she is the source of peace and harmony because she encourages James about reaching to the lighthouse one day. She is a "creative spirit", and a source of inspiration even when she is dead, embodied in the light at the window which helps Lily to focus on her painting (379). The light expresses the feelings of Mrs. Ramsay to herself and the reader. Her love for the sensitive world might be associated with spiritual longings and her being highly romantic (Stewart 381). Her insight moments and interior monologues provide a sense of liberation from "time and self". The lighthouse beam provides her "loss of self and fulfillment of being" (383). Mrs. Ramsay might be associated with the lighthouse in social terms, as well. At her exclusively important dinner, she takes on "the whole of the effort merging and flowing and creating" (131), observes her family members and guests, and analyzes their feelings and thoughts. In the section of "Time Passes", she dies and the beam of the lighthouse becomes, in a way, "ghost of her departed consciousness" by watching over the empty house. However, this time light becomes the shadow while consciousness turns to the unconscious (Stewart 384). While in the first two sections, the lighthouse stands for the source of life, in the last section, "The Lighthouse", it becomes the goal. It is the central figure of the novel; as it emanates light and it leads the paths to the same point of arrival. The voyage to the lighthouse is an ordinary activity but it builds integration. If the readers never arrive at the lighthouse, they are able to see it from many different points of view and may continue seeking their illumination from it.

Woolf handles time differently by demonstrating in her novel a kind of independence over the traditional understanding of time in order to affect a true and full representation of what goes on in the characters' consciousness. Mrs. Ramsay is the central consciousness in the novel whose form is inspired by the recognition of developing consciousness. There is no beginning and no end; besides, everything is relevant within consciousness and an indication of the total being in its ongoing process of formation (Gross 367). So, the novel is built upon a succession of random moments which Woolf gives much more attention than events of external significance. Through the consciousness of Mrs. Ramsay, over forty pages are devoted to an account of dinner which takes place in the opening section of the novel, while the sudden death of Mrs. Ramsay is only incidentally referred to a few pages later only in a parenthetical passage of four lines: "Mr. Ramsay, stumbling along a passage one dark morning, stretched his arms out, but Mrs. Ramsay having died rather suddenly the night before, his arms, through stretched out, remained empty" (143). Woolf's focus on the consciousness of a whole people in the house covers only two brief periods which are interrupted in the flow and expanded as space. Her excellent interest is about creating contrasts among the thoughts and emotions of the Ramsay family and their guests. A similar approach is felt when the death of Mrs. Ramsay and Andrew Ramsay in the war is only mentioned within brackets. In the novel, moments are randomly reproduced; however, nothing much happens. The novel is conducted by reflections of consciousness (Gross 368). Woolf intended to show the reader the contrasts between time as a process and time as a medium in the concept of fictional time. The first section, "The Window" and the third section "The Lighthouse" illustrate consciousness in a temporal medium by relying on the interior monologues.

For how would you like to be shut up for a whole month at a time, and possibly more in stormy weather, upon a rock the size of a tennis lawn? She would ask; and to have no letters and newspapers, and to see nobody; if you were married, not to see your wife, not to know how your children were, --if they were ill, if they had fallen down and broken their legs or arms; to see the same dreary waves breaking week after week, and then a dreadful storm coming, and the windows covered with spray, and birds dashed against the 
lamp, and the whole place rocking, and not be able to put your nose out of doors for fear of being swept into the sea? How would you like that? (9)

Here, what the character feels and thinks is presented in the manner of the author's straight narration by reflecting the character's consciousness and inner thoughts. The author uses indirect interior monologue. The conjunction 'for' applied at the beginning of the monologue, provides a natural shift from the objective descriptions to the character's inner state. Then, the phrases 'she would ask', 'she asked' arouse curiosity among the reader about Mrs. Ramsay's consciousness. In addition, the use of semicolons provides continuation for consciousness. Woolf's intervention to the novel in the disguise of an omniscient narrator guides reader in perceiving the mind of the character (Sang 174). In the second chapter, there is a transition from rendering consciousness to concentration on exterior changes, as the section is called "Time Passes". The mood of this section is harsh and insensitive; reflecting the merciless passing of time because towards the end of the section, it focuses on the fragmentation of the Ramsays' summer house in their absence. Initially, it depicts man as violent and destructive while depicting the woman as cooperated with nature (Aytaç 24). Mrs. Ramsay realizes the effects of time and expresses her worst fears: The fact that people, things, and relationships are inevitably changing frightens her.

a sort of transaction went on in which she was on one side, and life was on another, and she was always trying to get the better of it, as it was of her... she felt this thing that she called life terrible, hostile, and quick to pounce on you if you gave it a chance... Oh but she never wanted James to grow a day older! Or Cam either. These two she would have like to keep for ever just as they were... They were happier now than they would ever be again. (67-68)

It is understood that life always wins because it has time on its side. In this context, time is the enemy because it makes the conditions worse and people older. The stream of life which is reflected by the stream of consciousness is fearful for Mrs. Ramsay because the ongoing present time brings the unknown and unsettling future which is caused by the Great War. The past time makes her feel secure because it has already come through and, even though she experienced predicaments, she has gotten used to them. Now, she copes with them but she is not ready for other unfortunate incidents from which she wants to protect her children and preserve their peaceful moments.

As a conclusion, Woolf has a modernist treatment in her novel To the Lighthouse in which action does not develop and the progress is unexplored and discontinuous. The readers do not travel along a time course from point $\mathrm{A}$ to point $\mathrm{B}$. The storyline is merely portrayed to the reader as the points A and B exist separately. In other words, the consequences of A and B incidents should not necessarily be correlated. The mood of the characters changes and they undergo several recognitions but Woolf is not concerned to reveal why anything happens; she just shows what happens. She presents a vision of life in which inconsequential and random events in one's life have a more fulfilling and significant impact than external facts of birth, marriage, and death for one's existence. While doing so, she does not ignore the terrible consequences of the war; conversely, it is observed from the states of the characters, she experienced all of the troubles and devastations of the war and reflected them in her work. Indeed, the section "Time Passes" is the pure reflection of the chaos which war brought. While time passes, Woolf indicates the thought of death and reflects the unsettling state of characters caused by hopelessness. She concludes that time moves humans to death and material things and relations to an end. The concept of death is a natural outcome of the effects of - World War I which creates a sense of destruction and tragedy in individuals. In addition, Mrs. Ramsey's death and the war conditions affect Lily and, eventually, Lily finishes her painting. She consults her painting to solve the problems concerning intimacy. Now, she is mature and after the death of Mrs. Ramsay who was the figure of several traditional symbols for Lily, it is time to finish her painting because she is mentally ready to do so. She finally understands Mrs. Ramsay and accepts herself as she is. Lily's motivation in life is her art and creates intimacy with the dead Mrs. Ramsay because she can finally feel empathy towards her agonies and problems. Finally, she finishes her painting suddenly because she realizes her artistic talent. Also, she admits herself as an artist after she brings deceased Mrs. Ramsay back through her abstract portrait which is a success, achieving immortality through her art. In these respects, To the Lighthouse is the great representation of Woolf's unique style including 
themes of time concept, change in characters' lives, losses in action, and memory for the individuals and stream of consciousness technique and interior monologues to explore the problems of disappointed modern individuals due to great losses and drastic changes in both culture and daily life. Even though the novel does not reach a definite conclusion and leaves the questions about the meaning of life unanswered, Woolf creates her own style of modern fiction by using the themes of life and death and confronted her readers with the inevitable realities of the cruel world.

\section{WORKS CITED}

Akşehir, Mahinur, Atalay Gündüz, and Eda Burcu Çetinkaya. "The First World War and Women as the Victims of War Trauma in Virginia Woolf's Novels." Journal of Arts \& Humanities 4.Special (2017): 3-11. Web. 2019.

Aytaç, Esra Iffet. "Treatment of Death and Mourning in To the Lighthouse." Ed. Betüre Memmeova. Ç.Ü. Sosyal Bilimler Enstitüsü Dergisi 20.1 (2011): 77-86. Web.

Aytaç, Esra Iffet. Analysis of the Concept of Death and Mourning in Virginia Woolf's To the Lighthouse. Thesis. Isparta/ Süleyman Demirel University, 2009. SDÜ Sosyal Bilimler Enstitüsü, 2009. 1-75. Web.

Bradbury, Malcolm. "The Name and Nature of Modernism." Ed. Malcolm Bradbury and James McFarlane. Modernism: A Guide to European Literature 1890-1930. London: Penguin, 1991. 19-51. Print.

Collins, Laura Anne, "Abstracting Intimacy: Lily Briscoe's Artistic Vision in To the Lighthouse" (2005). Chancellor's Honors Program Projects. Web.

DiBattista, Maria. Imagining Virginia Woolf: An Experiment in Critical Biography. Princeton UP, 2009. Print.

Gaipa, Mark. "An Agnostic's Daughter's Apology: Materialism, Spiritualism, and Ancestry in Woolf's "To the Lighthouse"." Journal of Modern Literature 26.2 (2003): 1-41. JSTOR. Web. 2019.

Gillies, Mary Ann, and Aurelea Mahood. Modernist Literature: An Introduction. Edinburgh UP, 2007. Print.

Goldman, Jane. The Cambridge Introduction to Virginia Woolf. Cambridge UP, 2006. Print.

Guth, Deborah. "Virginia Woolf: Myth and "To the Lighthouse"." College Literature 11.3 (1984): 233-49. JSTOR. Web. 2019.

Gross, Beverly. "Narrative Time and the Open-Ended Novel." Criticism 8.4 (1966): 362-376. JSTOR. Web. 2019.

Rayment, Andrew. "Literary Realism, Modernism and Postmodernism: A Comparative Introduction." Chiba U, Japan, 2017. Web.

Sang, Yanxia. "An Analysis of Stream-of-Consciousness Technique in To the Lighthouse." Asian Social Science 6.9 (2010):173-179. Web.

Stewart, Jack F. "Light in To the Lighthouse." Twentieth Century Literature 23.3 (1977) :377389. JSTOR. Web. 2019.

Wood, Joanne A. "Lighthouse Bodies: The Neutral Monism of Virginia Woolf and Bertrand Russell." Journal of the History of Ideas 55.3 (1994): 483-502. JSTOR. Web. 2019.

Woolf, Virginia. "Modern Fiction." Ed. Andrew McNeillie. The Essays of Virginia Woolf. Vol. 4. London: Hogarth, 1984. 157-65. Print.

Woolf, Virginia. The Diary of Virginia Woolf: 1925-1930. Ed. Anne Olivier Bell. Vol. 3. Florida: Harcourt Brace\& Company, 1980. Print.

Woolf, Virginia. To the Lighthouse. Istanbul: MK Publications, 2017. Print. 